\title{
Contextual factors related to chronic condition in portuguese adolescents: highlights from the HBSC/WHO study
}

\author{
Teresa Santos ${ }^{1,3^{*}}$, Margarida Gaspar de Matos ${ }^{1,2,3}$, Maria Celeste Simões ${ }^{1,2}$ and Maria do Céu Machado ${ }^{4}$
}

\begin{abstract}
Adolescence's changes may become more pronounced when living with a chronic condition (CC). This study aims to examined the differences in satisfaction with family life, perception of school competence and "pressure with homework" of Portuguese adolescents' 1) living with CC; 2 ) how living with CC affects school participation; taking into account age, gender and family socioeconomic status (SES).

Five thousand fifty Portuguese adolescents (mean age $14 \pm 1.85$ ) of the Health Behaviour in School-aged Children ( $\mathrm{HBSC}$ WHO) were included. Results showed increased vulnerability in adolescents living with CC, presenting a lower satisfaction with family life and poor school outcomes. Younger boys, having a higher SES and not having CC are significantly associated with satisfaction with family life. Older girls, having a lower SES and living with CC were associated with more stress related to school work.

Future interventions should include these features combined with 'listening' to adolescents and their needs, allowing their participation in the promotion of personal health.
\end{abstract}

Keywords: Adolescents, Chronic condition, Satisfaction with family life, School perception, Socioeconomic status

\section{Background}

Research that compares adolescents with and without a chronic condition (CC), or different diseases, has been contradictory (Combs-Orme et al. 2002). Some studies suggest an increased risk in chronic population (Barlow and Ellard 2006), while others suggest the possibility of a successful adaptation (Barros et al. 2008). Responses are not homogeneous and depend on various specific individual and contextual factors, on the type of disease/condition and on emerging limitations (Lee et al. 2013). In spite of medical advances, children and adolescents living with a CC still face numerous challenges and can be at higher risk for a healthy psychological development (Verhoof et al. 2012), psychological well-being (Santos et al. 2015) and more adjustment problems (Oeseburg et al. 2010a).

\footnotetext{
* Correspondence: gaudi_t@hotmail.com

${ }^{1}$ FMH, Faculdade de Motricidade Humana (Projecto Aventura Social-Social Adventure Team)/Universidade de Lisboa, Lisboa, Portugal

${ }^{3}$ William James Center of Research, ISPA - Instituto Universitário, Ciências

Psicológicas, Sociais e da Vida, Lisboa, Portugal

Full list of author information is available at the end of the article
}

The effects of a CC extend to the entire family system (Quittner et al. 2011), which can be a major adaptation facilitator or, on the contrary, a barrier to adjustment (Braconnier and Marcelli 2000). Parents and parental styles are important in the adaptation process to diseases (Santos et al. 2013a). However, in those situations, parents seem to be more restrictive, overprotective and authoritarian; still, most families have a good overall functioning and adaptation (Pinquart 2013). Good communication (Hartos and Power 1997), a secure attachment relationship, a democratic parenting style and a good social support network are suggested as important protective familiar factors, both in children and adolescents (Moreno 2004).

In addition, adolescents living with a CC can also experience numerous school difficulties (Harris et al. 2013) and academic setbacks (Bethell et al. 2012) including truancy (Boonen and Petry 2012), poor academic performance, poor self-perception of academic competence, impaired ability to cope with the demands of a classroom (Logan and Simons 2010), gaps in knowledge/low cognitive development, decreased readiness to learn (Layte and McCrory 2012) and isolation from peer

\section{Springer}


group (Mazur and Małkowska-Szkutnik 2010). Young people's perceived school performance and feeling pressured by schoolwork can influence a wide range of nonacademic outcomes such as health, health behaviour and well-being (Currie et al. 2012). Missing school, grade retention and school problems are potentially impeding school success variables, placing those adolescents at higher risk for poor educational, vocational and social outcomes in adulthood (Maslow et al. 2011).

However, the individual's perception of disease and adaptation to a CC is a dynamic and changeable process, moderated by gender, age, corresponding socio-cognitive developmental level (Holden et al. 1997), real perception, exposure to cultural/familiar beliefs and construction of concepts of health/illness (Taylor et al. 2008). Generally, in Europe, school pressure increases with age and is higher in older girls and younger boys. Perceived good academic achievement tend to decrease with age, and girls are more likely to enjoy school and report higher school performance (Currie et al. 2012). In addition, crosscultural data suggests an association between better health and financial satisfaction (Oishi et al. 1999; Olén et al. 2012). Thus, high SES adolescents have better classmate support, communication with mother/father and a higher perceived academic achievement (Currie et al. 2012). On the opposite, students living with a CC from lower socio economic status (SES) families tend to miss school classes more frequently (Meng et al. 2012) and are at higher risk of perceiving school work and demands as "heavy" (Mazur and Małkowska-Szkutnik 2010).

In Portugal, the studies Health Behaviour SchoolAged Children (HBSC/WHO) (Matos and Equipa Aventura Social 2000) and Kidscreen (Gaspar and Matos 2008) have shown similar tendencies, suggesting higher vulnerability population with chronic conditions. These studies also point out the importance of a good communication with parents and peers for adolescents' health (Matos et al. 2006; Tomé et al. 2012) and that school satisfaction is related with higher scores of academic achievement (Simões et al. 2010). In addition, difficulties in communication are associated with violent behaviors in school and also with both physical and psychological symptoms; while a better parental communication is associated with feeling happier (Matos and Equipa Aventura Social 2000). Further details on Portuguese data concerning chronic diseases and in adolescents, related to individual factors, risk behaviours and psychological well-being have been already published (Santos et al. 2013b; Santos et al. 2014; Santos et al. 2015). It seems, therefore, relevant to study the impact of: 1) living with a chronic condition; and 2) living with a chronic condition that affects school participation, and its association with satisfaction with family life (Cantril 1965), "Feeling pressure with homework" and "Perception of school competence". The demographic factors studied within these variables are age, gender and family SES by a proxy (FAS: Family Affluence Scale) (Boyce et al. 2006).

\section{Method}

\section{Participants}

The present study refers to the Portuguese HBSC 2010 study (Matos et al. 2012a, b), consisting of 5050 Portuguese adolescents attending the $6^{\text {th }}, 8^{\text {th }}$ and $10^{\text {th }}$ grades, randomly selected from 256 classes and 125 national public schools. From the total group of adolescents were included all $(N=4647)$ that answered the question corresponding to having or not having a long term disease or health problem that has been diagnosed by a doctor (missing values excluded). These group has a mean age of 14 years $(S D=1.85$, it is composed by $52.3 \%$ girls and $47.7 \%$ boys and the majority of the participating children and adolescents have Portuguese nationality (94.4\%).

\section{Research design and questionnaire}

A self-administered questionnaire from the Portuguese study of the Health Behaviour in School-aged Children (HBSC) was used. This study has been carried on every 4 years since 1996 (Matos and Equipa Aventura Social 2000).

HBSC is a school-based, self-report questionnaire developed cooperatively between international researchers according to protocol, and used in collaboration with the World Health Organization to assess children and adolescents' mental and physical health (Currie et al. 2001; Currie et al. 2009; Roberts et al. 2009).

The aim of the study is to understand health behaviours and well-being among adolescents, within their social context (Roberts et al. 2007). Especially designed to be appropriate for adolescents aged 11-15, this survey consists of items measuring background factors (e.g., socioeconomic status, family structure), individual and social resources (e.g., body image, school environment), health behaviours (e.g., smoking, dieting, sexual behaviour, violence), and health outcomes (e.g., life satisfaction, psychological well-being, and self-reported health). For the purpose of the present work a set of variables was selected, described in Table 1).

\section{Measures}

For the purpose of this study, the group of students living with a CC was composed by those who gave an affirmative answer to the question: "Do you have any long term disease or health problem that has been diagnosed by a doctor?" In a second step, participants were inquired on 
Table 1 Variables included in the study

\begin{tabular}{|c|c|}
\hline Study variables & Range \\
\hline Gender & $1=$ Boy; $2=$ Girl \\
\hline Age & Min $=11$ years old; $\operatorname{Max}=16$ years old \\
\hline $\begin{array}{l}\text { Having or not having a long term disease or health } \\
\text { problem that has been diagnosed by a doctor } \\
\text { (Having/not having a chronic condition - CC); }\end{array}$ & $1=\mathrm{No} ; 2=\mathrm{Yes}$ \\
\hline $\begin{array}{l}\text { Feeling that the disease affects or not participation } \\
\text { and regular attendance in school; }\end{array}$ & $1=\mathrm{No} ; 2=\mathrm{Yes}$ \\
\hline Satisfaction with family life (Cantril, 1965) & $0=$ Very bad relationship; $1 ; 2 ; 3 ; 4 ; 5 ; 6 ; 7 ; 8 ; 9 ; 10=$ Very good relationship \\
\hline \multicolumn{2}{|l|}{$\begin{array}{l}\text { Family Affluence Scale -FAS (Boyce et al., 2006): } \\
\text { composed by } 4 \text { items, and used to assess familiar } \\
\text { socioeconomic status (SES): }\end{array}$} \\
\hline "Does your family have a car, van or other mean of transport?" & $1=$ No; $2=$ Yes, one; $3=$ Yes, two or more \\
\hline "How many computers do you have at home?" & $1=$ None; $2=$ One; $3=$ Two; $4=$ More than two \\
\hline Spending holidays with family in the last 12 months & $1=$ None; $2=$ One; $3=$ Two; $4=$ More than two \\
\hline "Do you have a bedroom only for yourself?" & $1=$ No; 2 = Yes \\
\hline "Feeling pressure with homework" & $1=$ None; $2=\mathrm{A}$ few $; 3=$ Some; $4=\mathrm{A}$ lot \\
\hline "Perception of school competence" & $1=$ Very good; $2=$ Good; $3=$ Average; $4=$ Below average \\
\hline
\end{tabular}

the extent to which having chronic disease affects school participation. Other variables included in this study are described in Table 1.

\section{Procedure}

Data was collected in 139 schools, randomly selected from the official national list of public schools, stratified by region. In each school, according to the international protocol, the class was the analysis's unity and classes were randomly selected in order to meet the required number of students for each grade (Currie et al. 2001). The HBSC study followed all the research rules defined by the Portuguese Ministry of Education and Regional Offices of Education, and was approved by the scientific committee, national ethics committee and national data protection. All participating schools collected informed parental consent.

Questionnaires were sent to schools and, according to the protocol, teachers administered the questionnaires in the classroom with voluntary's student participation. Confidentiality was ensured with anonymous response to the questionnaire and restricted access to HBSC research team members. The response rate was of $92 \%$ for schools.

\section{Data analysis}

Data was analysed using the Statistical Package for Social Sciences (SPSS), version 19.0 for Windows. After a descriptive analysis, ANOVA was used to compare life satisfaction and Familly affluence in the different CC conditions, Qui-square tests were used to analyse the distribution of gender, age groups, school competence and pressure with schoolwork in the different CC conditions and finally Multiple Linear Regressions were used to determine the relationship and the strength of the associations between the variables.

\section{Results}

The majority of the children and adolescents do not have a $C C(81 \% ; N=3763)$, and the group who has (19\%; $N=884$ ) mainly reports chronic diseases $(88.2 \%)$, followed by sensorial $(5.2 \%)$, motor $(4.4 \%)$ and cognitive/psychological (2.2\%) conditions. Teens that indicate to have a chronic health condition mostly report that the disease does not affect their participation and regular attendance in school (85.7\%; $N=1180)$.

Qui-Square tests were used to better understand specific differences or associations between the study variables and 1) having or not a $\mathrm{CC}$, and 2) if that $\mathrm{CC}$ affects or not participation and regular attendance in school.

"Having or not a chronic condition" (Table 2) was not significantly associated with gender or "Perception of school competence". Data showed a significantly different distribution according to "Feeling pressure with school homework" [ $\left.\chi^{2}(3, N=4582)=17.48, p \leq 0.001\right]$. Adolescents living with a CC present more frequently (15.5\%) "Feel like that a lot" compared with adolescents without chronic condition (11.5\%).

"Having a chronic condition (CC) and feeling that it affects or not the participation and regular attendance in school" (Table 2) were not significantly associated with gender nor with "Feeling pressure with homework". However, a significant association was found regarding "Perception of school competence" $\left[\chi^{2}(3, N=1366)=10.96, p \leq 0.05\right]$. Adolescents with a chronic condition who feel that the 
Table 2 Bivariate analysis ( $\left.X^{2}\right)$ of study independent variables and 1) having or not a chronic condition (CC), and 2) CC affecting or not participation/regular attendance in school

\begin{tabular}{|c|c|c|c|c|c|c|c|c|}
\hline \multirow{3}{*}{$\overline{\text { Background }}$} & & \multicolumn{7}{|c|}{ Adolescents } \\
\hline & & \multicolumn{2}{|c|}{ Without CC } & \multicolumn{2}{|c|}{ With CC } & \multirow[t]{2}{*}{ Total } & \multirow[t]{2}{*}{$x^{2}$} & \multirow[t]{2}{*}{ Df } \\
\hline & & $N$ & $\%$ & N & $\%$ & & & \\
\hline \multirow[t]{2}{*}{ Gender } & Boy & 1797 & 47.8 & 395 & 44.7 & 2192 & 2.709 & 1 \\
\hline & Girl & 1966 & 52.2 & 489 & 55.3 & 2455 & $(p=0.100)$ & \\
\hline \multirow[t]{4}{*}{ "Perception of school competence" } & Very good & 325 & 8.7 & 81 & 9.2 & 406 & 0.346 & \\
\hline & Good & 1415 & 37.9 & 331 & 37.6 & 1746 & $(p=0.951)$ & 3 \\
\hline & Average & 1781 & 47.7 & 416 & 47.3 & 2197 & & \\
\hline & Bellow average & 210 & 5.6 & 52 & 5.9 & 262 & & \\
\hline \multirow[t]{6}{*}{ "Feeling pressure with homework" } & None & 802 & 21.6 & 148 & 17 & 950 & $17.478^{* * *}$ & 3 \\
\hline & A few & 1092 & 29.4 & 244 & 28 & 1336 & $(p=0.001)$ & \\
\hline & Some & 1390 & 37.4 & 343 & 39.4 & 1733 & & \\
\hline & A lot & 428 & 11.5 & 135 & 15.5 & 563 & & \\
\hline & & \multicolumn{2}{|c|}{ CC Does not Affect School } & \multicolumn{2}{|c|}{ CC Affects School } & Total & $x^{2}$ & Df \\
\hline & & $N$ & $\%$ & N & $\%$ & & & \\
\hline \multirow[t]{2}{*}{ Gender } & Boy & 566 & 48.0 & 99 & 50.3 & 665 & 0.354 & 1 \\
\hline & Girl & 614 & 52.0 & 98 & 49.7 & 712 & $(p=0.552)$ & \\
\hline \multirow[t]{4}{*}{ Perception of school competence } & Very good & 103 & 8.8 & 19 & 9.7 & 122 & $10.964^{*}$ & 3 \\
\hline & Good & 426 & 36.4 & 61 & 31.3 & 487 & $(p=0.012)$ & \\
\hline & Average & 567 & 48.4 & 90 & 46.2 & 657 & & \\
\hline & Bellow average & 75 & 6.4 & 25 & 12.8 & 100 & & \\
\hline \multirow[t]{4}{*}{ "Feeling pressure with homework" } & None & 223 & 19.2 & 34 & 17.5 & 257 & 6.068 & 3 \\
\hline & A few & 342 & 29.5 & 51 & 26.3 & 393 & $(p=0.108)$ & \\
\hline & Some & 429 & 37 & 68 & 35.1 & 497 & & \\
\hline & A lot & 166 & 14.3 & 41 & 21.1 & 207 & & \\
\hline
\end{tabular}

Indicates significant differences for the following levels: ${ }^{* *} p \leq .001 ;{ }^{*} p \leq .05$

disease affects school participation, more frequently (12.8\%) "Feel like being a student below average" than adolescents who felt that the disease does not affect school participation (6.4\%).

ANOVA was used to analyze the differences between adolescents' satisfaction with family life (Table 3) data showed statistical differences between adolescents having or not a $\mathrm{CC}$, and between adolescents feeling that CC affects or not participation in school. The group who does not have a CC has in average higher satisfaction with family life $(F(1.4541 ; 15.47, p \leq .001)(M=8.52$, $S D=1.88$ ), and the same in the group who has a CC but does not feel it affects participation in school $(F(1.1335$; $19.29, p \leq .001)(M=8.41, S D=1.94)$.

Adolescents' family affluence (FAS) showed no significant difference regarding having or not a CC. Nevertheless, the group who has a CC but feels that the disease does not affect participation in school, has a higher FAS $(F(1.1331 ; 5.27, p \leq .05)(M=5.86, S D=1.86)$.

A set of multiple linear regression models was carried out to estimate the relationship between: 1) adolescents' satisfaction with family life, 2) adolescent's "Feeling pressure with school homework", and 3) adolescent's "Perception of school competence", using as predictors gender, age, socioeconomic status (Family Affluence Scale -FAS) and the chronic disease "status": having or not a CC (Table 4), or, feeling that CC affects or not participation and regular attendance in school (Table 5).

\section{Chronic condition (Table 4)}

An adjusted model was achieved for satisfaction with family life $[F(4)=50.611, p \leq .05]$, and the variance explained by the final model was of $4.3 \%$. Table 4 shows that although all the four independent variables in the equation are significantly associated to satisfaction with family life, there is a low impact of gender, FAS and having a CC. The higher association is with age (older adolescents feeling worst about family life), and, although with a much lower impact, being a girl and having a CC makes adolescents feel worst about family life. Also in a lower impact, the adolescents who have higher FAS feel more satisfied with family life. 
Table 3 Adolescents' satisfaction with family life and FAS comparing 1) having or not CC, and 2) feeling that CC affects or not school participation (ANOVA)

\begin{tabular}{|c|c|c|c|c|c|c|c|}
\hline \multirow[b]{2}{*}{ Satisfaction with family life } & \multicolumn{7}{|c|}{ Adolescents } \\
\hline & \multicolumn{2}{|c|}{ With CC } & \multicolumn{5}{|c|}{ Without CC } \\
\hline & M & $S D$ & M & $S D$ & $F$ & Df & $P$ \\
\hline & 8.23 & 2.06 & 8.52 & 1.88 & $15.466^{* * *}$ & 1 & .000 \\
\hline & \multicolumn{2}{|c|}{ CC Affects School } & \multicolumn{5}{|c|}{ CC does not Affect School } \\
\hline & M & $S D$ & M & $S D$ & F & Df & $P$ \\
\hline & 7.71 & 2.47 & 8.41 & 1.94 & $19.293^{* * *}$ & 1 & .000 \\
\hline \multirow[t]{6}{*}{ FAS } & \multicolumn{2}{|c|}{ With CC } & \multicolumn{5}{|c|}{ Without CC } \\
\hline & M & $S D$ & M & $S D$ & $F$ & Df & $P$ \\
\hline & 5.91 & 1.84 & 5.88 & 1.83 & 0.291 & 1 & .590 \\
\hline & \multicolumn{2}{|c|}{ CC Affects School } & \multicolumn{5}{|c|}{ CC does not Affect School } \\
\hline & M & SD & M & $S D$ & $F$ & Df & $P$ \\
\hline & 5.53 & 1.84 & 5.86 & 1.86 & $5.277^{*}$ & 1 & .022 \\
\hline
\end{tabular}

Indicates significant differences for the following levels: ${ }^{* * *} p \leq .001 ;{ }^{*} p \leq .05$

An adjusted model was achieved for "Feeling pressure with school homework" $[F(4)=133.776, p \leq .05]$, and the variance explained by the final model was of $10.6 \%$. As for this variable, there is a significant but low impact of FAS and having a CC. The higher association is with age (older adolescents feeling more pressure), and with gender (girls reporting more pressure). Although with a much lower impact, not having a CC and reporting a higher FAS makes adolescents feel more "pressure with school homework".

Finally, an adjusted model was achieved for the "Perception of school competence" $[F(4)=76.944, p \leq .05]$ and the variance explained by the final model was of $6.4 \%$. For this variable there is no significant impact of gender, and there is a significant but low impact of having a CC. The higher association is with age (older adolescents reporting lower school competence), and with FAS (more affluent adolescents reporting more competence) and, although with a much lower impact, having a CC makes adolescents have a higher perception of school competence.

\section{Chronic condition affecting participation and regular attendance in school (Table 5)}

Table 5 repeat the same models but instead of the variable having/not having a CC, it considers whenever "CC affects/not affects school participation".

Table 4 Predicting 1) Adolescents' satisfaction with family life and 2) "Feeling pressure with school homework" and "perception of school competence, using as predictors gender, age, FAS and having or not a CC (multiple linear regression model)"

\begin{tabular}{|c|c|c|c|c|c|c|}
\hline & Included Variables & $B$ & Std. Error & $\beta$ & $t$ & $R^{2}$ \\
\hline \multirow[t]{4}{*}{ Satisfaction with family life ${ }^{a}$} & Gender $\hat{o}-q$ & -.169 & .057 & -.044 & $-2.982^{* *}$ & .043 \\
\hline & Age & -.185 & .015 & -.178 & $-12.097^{* * *}$ & \\
\hline & FAS & .077 & .016 & .073 & $4.975^{* * *}$ & \\
\hline & Having or not a CC & -.278 & .072 & -.057 & $-3.865^{* * *}$ & \\
\hline \multirow[t]{4}{*}{ "Feeling pressure with school homework" b } & Gender $\hat{\sigma}-q$ & .288 & .027 & .152 & $10.721^{* * *}$ & .106 \\
\hline & Age & .145 & .007 & .283 & $19.954^{* * *}$ & \\
\hline & FAS & .024 & .007 & .046 & $3.254^{* * *}$ & \\
\hline & Having or not a CC & -129 & .034 & .053 & $3.778^{* *}$ & \\
\hline \multirow[t]{4}{*}{ "Perception of school competence" c } & Gender $\widehat{\partial}-q$ & .035 & .022 & .023 & 1.600 & .064 \\
\hline & Age & -.086 & .006 & -.210 & $-14.493^{* * *}$ & \\
\hline & FAS & .053 & .006 & .128 & $8.792^{* * *}$ & \\
\hline & Having or not a CC & .072 & .028 & .037 & $2.564^{* * *}$ & \\
\hline
\end{tabular}

$B$ and Std. Error: unstandardized coefficients; $\beta$ : standardized coefficients

${ }^{* * *} p \leq .001 ;{ }^{* *} p \leq .01$

${ }^{\text {a }} F=50.611$

b $F=133.776$

${ }^{c} F=76.944$ 
Table 5 Predicting 1) adolescents' satisfaction with family life and 2) "feeling pressure with school homework" and "perception of school competence, using as predictors gender, age, FAS and feeling that CC affects or not school participation (multiple linear regression model)"

\begin{tabular}{|c|c|c|c|c|c|c|}
\hline & Included Variables & $B$ & Std. Error & $\beta$ & $t$ & $R^{2}$ \\
\hline \multirow[t]{4}{*}{ Satisfaction with family life ${ }^{\text {a }}$} & Gender $\hat{o}-q$ & -.166 & .111 & -.040 & -1.491 & .046 \\
\hline & Age & -.179 & .030 & -.161 & $-5.919^{* * *}$ & \\
\hline & Socioeconomic Status (FAS) & .068 & .030 & .062 & $2.276^{*}$ & \\
\hline & Feeling CC affects/not affects school & -.662 & .160 & -.113 & $-4.139^{* * *}$ & \\
\hline \multirow[t]{4}{*}{ "Feeling pressure with school homework" b } & Gender $\hat{o}-q$ & 0.269 & 0.050 & 0.139 & $5.363^{* * *}$ & 0.120 \\
\hline & Age & 0.166 & 0.014 & 0.317 & $12.142^{* * *}$ & \\
\hline & Socioeconomic Status (FAS) & 0.017 & 0.014 & 0.033 & 1.255 & \\
\hline & Feeling CC affects or not school & 0.090 & 0.072 & 0.033 & 1.254 & \\
\hline \multirow[t]{4}{*}{ "Perception of school competence" c } & Gender $\hat{o}-q$ & -0.064 & 0.040 & -0.042 & -1.585 & .053 \\
\hline & Age & 0.069 & 0.011 & 0.167 & $6.195^{* * *}$ & \\
\hline & Socioeconomic Status (FAS) & -0.60 & 0.011 & -0.147 & $-5.563^{* * *}$ & \\
\hline & Feeling CC affects or not school & 0.037 & 0.058 & 0.017 & 0.631 & \\
\hline
\end{tabular}

B and Std. Error: unstandardized coefficients; $\beta$ : standardized coefficients

${ }^{* * *} p \leq .001 ;{ }^{*} p \leq .05$

${ }^{\text {a }} F=16.497$

${ }^{\text {b }} F=45,462$

c $F=19,620$

An adjusted model was achieved for satisfaction with family life $[F(4)=16.497, p \leq .05]$, and the variance explained by the final model was of $4.6 \%$. Considering satisfaction with family life, there is no significant impact of gender and a low impact of FAS. The higher association is with age (older adolescents feeling worst with family life) and having a CC that affects school participation makes adolescents feel worst with family life, with a much higher impact than merely considering having or not a CC. With a much lower impact, having a higher FAS makes adolescents feel more satisfaction with family life.

An adjusted model was also achieved for "Feeling pressure with school homework" $[F(4)=45.462, p \leq .05]$, and the variance explained by the final model was of $12 \%$. As for this variable, there is no significant impact of FAS and of having a CC that affects school participation. The higher association is with age (older adolescents feeling more pressure), and with gender (girls reporting more pressure).

Finally an adjusted model was achieved for "Perception of school competence" $[F(4)=19.620, p \leq .05]$, and the variance explained by the final model was of $5.3 \%$. For this variable there is no significant impact of gender nor of having a CC that affects school participation. The higher association is with age (older adolescents reporting higher school competence), and with FAS (more affluent adolescents reporting less competence).

Interestingly age seems the worst "risk factor" for (in) satisfaction with family life, pressure with school work and (low) perception of school competence. Focusing on CC, having a CC has a significant but really low impact upon those situations. Interestingly as well is that when considering only having a CC that affects school participation, the impact upon school pressure and perception of school competence decreases, and the impact upon family life increases.

\section{Discussion}

A brief overview of main results shows that adolescents living with a CC present higher levels of "pressure with homework" and feel that their school competence is below average. On the other hand, adolescents living without a CC perceive their satisfaction with family life as more satisfying. This data supports the hypothesis evidenced in the literature, proposing that adolescents living with a CC may have increased risk and vulnerability (Barlow and Ellard 2006; Gaspar and Matos 2008; Matos and Equipa Aventura Social 2000; Oeseburg et al. 2010a, b; Santos et al. 2013a, b; Santos et al. 2014; Verhoof et al. 2012), mainly in satisfaction with family life (Michaud et al. 2007; Quittner et al. 2011) and school success (Bethell et al. 2012; Layte and McCrory 2012).

This study also supports previous research that suggests changes can be influenced by gender, age and SES (Currie et al. 2012; Holden et al. 1997; Oishi et al. 1999; Olén et al. 2012; Taylor et al. 2008).

Parents have an important role in the adaptation process to a CC and, concerning school outcomes, parental encouragement can be considered to have a specific positive effect on adolescent health, beyond the effect of school environment and family communication addressed individually (Matos et al. 2006). Thus, family 
is necessarily an intervention target when pediatric disabling conditions occur in order to help parents deal with children/adolescents' $\mathrm{CC}$ and associated changes in the family environment (Russo et al. 2012). Parental interventions should provide key aspects focused on educational, therapeutic and organizational dimensions.

This study has some limitations namely findings were entirely based on adolescents' self-reports (a widely-used procedure in a national survey design) and the results are cross-sectional (and not ideally longitudinal). Notwithstanding these limitations, this is one of the first investigations concerning the impact of living and attending school in adolescents with $\mathrm{CC}$, using a wide national representative study (HBSC Portuguese study).

\section{Conclusions}

Adolescents frequently feel that their lives are ruled by the medical system and so it is increasingly important to include their perspectives in healthcare, highlighting their specific needs, knowledge, competences and rights (Matos et al. 2013; Michaud et al. 2004; Ottova et al. 2013). It is also important to consider their suggestions to parents, such as learning better parenting styles, having greater confidence in their children, and gradually transferring to them the responsibility for medical treatment (Bregnballe et al. 2011).

Therefore, a multifaceted approach and prevention of CCs in schools is highlighted and may reduce the costs of special education services, help adolescents to better control the disease and improve a healthy development into adulthood (Logan and Simons 2010). In addition, when designing and implementing school-based intervention programs, it seems important to promote school assets as important features on school satisfaction and academic achievement for all students and, in particular, for those more vulnerable to achieve success (Simões et al. 2010). Building competences in adolescents with a $\mathrm{CC}$, strengthening connectedness and a better communication within the family, school, peer group and health care professionals will enhance resilience and increase the opportunities to improve health outcomes in this population, creating opportunities to support their school and future professional career (Matos et al. 2012a, b; Oeseburg et al. 2010b).

\section{Competing interests}

None of the authors reported any financial interests or potential conflicts of interest.

\section{Authors' contributions}

TS and MGM conceived the study, participated in its design and coordination, draft and authored the manuscript; CS and MCM participated in the study design, interpretation of the data, and helped to draft manuscript revisions. All authors read and approved the final manuscript.

\section{Acknowledgements}

The authors would like to thank "Aventura Social" team members for their work on data collection and management. HBSC/WHO 2010 in Portugal was co-financed by Alto Comissariado da Saúde, Ministério da Saúde (High Commission for Health, Health Ministry) and Coordenação Nacional para a Infecção VIH/SIDA (National Coordination for HIV/AIDS).

\section{Funding}

Santos, T. is supported by a PhD grant from the Portuguese Foundation for Science and Technology (FCT) (Grant Number: reference SFRH/BD/82066/2011). The William James Center for Research, ISPA - Instituto Universitário is supported by a grant from the Portuguese Foundation for Science and Technology (FCT) (Grant Number: UID/PSI/04810/2013).

\section{Author details}

${ }^{1}$ FMH, Faculdade de Motricidade Humana (Projecto Aventura Social-Social Adventure Team)/Universidade de Lisboa, Lisboa, Portugal. ${ }^{2}$ ISAMB, Instituto de Saúde Ambiental, Faculdade de Medicina, Universidade de Lisboa, Lisboa, Portugal. ${ }^{3}$ William James Center of Research, ISPA - Instituto Universitário, Ciências Psicológicas, Sociais e da Vida, Lisboa, Portugal. ${ }^{4}$ Departamento de Pediatria do Hospital de Santa Maria, CAML, Centro Académico de Medicina de Lisboa, Lisboa, Portugal.

Received: 8 February 2016 Accepted: 2 March 2016

Published online: 13 April 2016

\section{References}

Barlow JH, Ellard DR. The psychosocial well-being of children with chronic disease, their parents and siblings: an overview of the research evidence base. Child Care Health Dev. 2006;32(1):19-31.

Barros L, Matos MG, Batista-Foguet J. Chronic diseases, social context and adolescent health: results of the Portuguese National Health Behaviour in school-aged children survey. Revista Brasileira de Terapias Cognitivas. 2008; 4(1):29.

Bethell C, Forrest CB, Stumbo S, Gombojav N, Carle A, Irwin CE. Factors promoting or potentially impeding school success: disparities and state variations for children with special health care needs. Matern Child Health J. 2012;16 Suppl 1:S35-43. http://dx.doi.org/10.1007/s10995-012-0993-z.

Boonen H, Petry K. How do children with a chronic or long-term illness perceive their school re-entry after a period of homebound instruction? Child Care Health Dev. 2012;38(4):490-6. http://dx.doi.org/10.1111/j.1365-2214.2011. 01279.x.

Boyce W, Torsheim T, Currie C, Zambon A. The family affluence scale as a measure of national wealth: validation of an adolescent self-report measure. Soc Indicator Res. 2006:78(3):473-87.

Braconnier A, Marcelli D. As mil faces da adolescência [The Thousend Faces of Adolescence]. Lisboa: CLIMEPSI Editores; 2000.

Bregnballe V, Schiøtz PO, Lomborg K. Parenting adolescents with cystic fibrosis: the adolescents' and young adults' perspectives. Patient Preference Adherence. 2011;5:563-70. http://dx.doi.org/10.2147/PPA.S25870.

Cantril $\mathrm{H}$. The pattern of human concerns. New Brunswick: Rutgers University Press; 1965.

Combs-Orme T, Helfinger CA, Simpkins C. Comorbidity of mental health problems and chronic health conditions in children. J Emotion Behav Disord. 2002;2:116-25.

Currie C, Samdal O, Boyce W, Smith R. HBSC, a WHO cross national study: research protocol for the 2001/2002 survey. Copenhagen: WHO; 2001.

Currie C, Gabhainn N, Godeau E, The International HBSC Network Coordinating Committee. The Health Behaviour in School-Aged Children: WHO collaborative cross-National (HBSC) study: origins, concept, history and development 1982-2008. Int J Public Health. 2009;54 Suppl 2:131-9. http:// dx.doi.org/10.1007/s00038-009-5404-x.

Currie C, Zanotti C, Morgan A, Currie D, De Looze M, Roberts C, et al. Social determinants of health and well-being among young people. Health Behaviour in School-aged Children (HBSC) Study: International Report from the 2009/2010 Survey. Copenhagen: WHO Regional Office for Europe; 2012

Gaspar T, Matos MG. Qualidade de Vida em Crianças e Adolescentes Versão portuguesa dos instrumentos Kidscreen-52 [Quality of Life in Children and Adolescents - Portuguese version of KIDSCREEN-52 instrument]. Lisboa: CMDT/FMH/FCT; 2008. 
Harris RF, Menard-Katcher C, Atkins D, Furuta GT, Klinnert MD. Psychosocial dysfunction in children and adolescents with eosinophilic esophagitis. J Pediatr Gastroenterol Nutr. 2013;57(4):500-5. http://dx.doi.org/10.1097/MPG. Ob013e31829ce5ad.

Hartos JL, Power TG. Mothers' awareness of their early adolescents' stressors: Relation between awareness and adolescent adjustment. J Early Adolesc 1997;17(4):371-89.

Holden EW, Chmielewski D, Nelson CC, Kager VA. Controlling for general and disease-specific effects in child and family adjustment to chronic childhood illness. J Pediatr Psychol. 1997;22(1):15-27.

Layte R, McCrory C. Paediatric chronic illness and educational failure: the role of emotional and behavioural problems. Soc Psychiatry Psychiatr Epidemiol. 2012;48(8):1307-16. http://dx.doi.org/10.1007/s00127-012-0609-3.

Lee SL, Cheung YF, Wong HSW, Leung TH, Lam TH, Lau YL. Chronic health problems and health-related quality of life in Chinese children and adolescents: a population-based study in Hong Kong. BMJ Open. 2013;3(1): e001183. http://dx.doi.org/10.1136/bmjopen-2012-001183.

Logan DE, Simons LE. Development of a group intervention to improve school functioning in adolescents with chronic pain and depressive symptoms: a study of feasibility and preliminary efficacy. J Pediatr Psychol. 2010;35(8):823-36. http://dx.doi.org/10.1093/jpepsy/jsq008.

Maslow GR, Haydon A, McRee AL, Ford CA, Halpern CT. Growing up with a chronic illness: social success, educational/vocational distress. J Adolesc Health. 2011;49:206-12.

Matos MG, Equipa Aventura Social. Aventura Social \& Saúde, A saúde dos adolescentes portugueses - Relatórios Nacionais do Estudo HBSC 2000, 2002 e 2006, [Social Adventure \& Health: Portuguese Adolescents's Health - Final report from HBSC 2000/02/06 Study]. Lisboa: CMDT/IHMT/UNL, FMH/UTL; 2000.

Matos MG, Dadds M, Barrett P. Family-related school issues and the mental health of adolescents: post hoc analyses of the portuguese national health behaviour in school-aged children survey data. J Fam Stud. 2006;12(2):261-75. http://dx.doi.org/10.5172/jfs.327.12.2.261

Matos MG, Gaspar T, Ferreira M, Tomé G, Camacho I, Reis M, et al. Keeping a focus on self-regulation and competence: "find your own style", a school based program targeting at risk adolescents. J Cogn Behav Psychotherapies. 2012a;12(1):39-48.

Matos MG, Simões C, Tomé G, Camacho I, Ferreira M, Ramiro L, et al. Aventura Social \& Saúde, A Saúde dos adolescentes portuqueses - Relatório Final do Estudo HBSC 2010. Lisboa: CMDT/IHMT/UNL; FMH/UTL; 2012b.

Matos MG, Tomé G, Santos T, Gaspar T, Ramiro L, Consórcio RICHE/UE. RICHE: Trajetórias para a saúde da criança e do adolescente em Portugal. Lisboa: Centro Malária e Outras Doenças Tropicais/IHMT/UNL; FMH/Universidade Técnica de Lisboa; 2013

Mazur J, Małkowska-Szkutnik A. Chronic diseases and perception of school demands among school children aged 11-15 years in Poland. Medycyna Wieku Rozwojowego. 2010;14(2):160-8

Meng Y, Babey SH, Wolstein J. Asthma-related school absenteeism and school concentration of low-income students in California. Prev Chronic Dis. 2012;9: 110312. http://dx.doi.org/10.5888/pcd9.110312.

Michaud PA, Suris JC, Viner R. The adolescent with a chronic condition. Part II: healthcare provision. Arch Dis Child. 2004;89:943-9. http://dx.doi.org/10.1136/ adc.2003.045377.

Michaud PA, Suris JC, Viner R. The Adolescent with a Chronic Condition. Epidemiology, developmental issues and health care provision. Geneva: Department of Child and Adolescent Health and Development. WHO Discussion Papers on adolescence; 2007.

Moreno C. Desenvolvimento social durante a adolescência [Social Development During Adolescence]. In: Coll C, Marchesi A, Palácios J, et al., editors. Desenvolvimento psicológico e educação, Vol. 1-Psicologia Evolutiva. 2nd ed. Porto Alegre: Artmed; 2004. p. 350-70

Oeseburg B, Jansen DE, Groothoff JW, Dijkstra GJ, Reijneveld SA. Emotional and behavioural problems in adolescents with intellectual disability with and without chronic diseases. J Intellect Disabil Res. 2010a;54(1):81-9. http://dx. doi.org/10.1111/j.1365-2788.2009.01231.x

Oeseburg B, Jansen DE, Reijneveld SA, Dijkstra GJ, Groothoff JW. Limited concordance between teachers, parents and healthcare professionals on the presence of chronic diseases in ID-adolescents. Res Dev Disabil. 2010b;31(6): 1645-51. http://dx.doi.org/10.1016/j.ridd.2010.04.015

Oishi S, Diener EF, Lucas RE, Suh EM. Cross-cultural variations in predictors of life satisfaction: perspectives from needs and values. Pers Soc Psychol Bull. 1999; 25(8):980-90.
Olén O, Bihagen E, Rasmussen F, Ludvigsson JF. Socioeconomic position and education in patients with coeliac disease. Dig Liver Dis. 2012;44(6):471-6. http://dx.doi.org/10.1016/j.dld.2012.01.006.

Ottova V, Alexander D, Rigby M, Staines A, Hjern A, Leonardi M, Ravens-Sieberer $U$, The RICHE Project Group. Report on the roadmaps for the future, and how to reach them. 2013; http://doras.dcu.ie/19732/1/WP4_D8_RICHE_ Roadmap.pdf

Pinquart M. Do the parent-child relationship and parenting behaviors differ between families with a child with and without chronic illness? A metaanalysis. J Pediatr Psychol. 2013;38(7):708-21. http://dx.doi.org/10.1093/ jpepsy/jst020.

Quittner AL, Romero SL, Kimberg Cl, Blackwell LS, Cruz I. Chronic Illness. Encyclopedia Adolesc. 2011;3:91-9.

Roberts C, Currie C, Samdal O, Currie D, Smith R, Maes L. Measuring the health behaviours of adolescents through cross-national survey research: recent developments in the Health Behaviour in School-aged Children (HBSC) study. J Public Health. 2007;15(3):179-86.

Roberts C, Freeman J, Samdal O, Schnohr C, Looze S, Gabhainn N, et al. The Health Behaviour in School-aged Children (HBSC) study: methodological developments and current tensions. Int J Public Health. 2009;54 Suppl 2:140-50. http://dx.doi. org/10.1007/s00038-009-5405-9.

Russo E, Trevisi E, Zulian F, Battaglia MA, Viel D, Facchin D, Martinuzzi A Psychological Profile in Children and Adolescents with Severe Course Juvenile Idiopathic Arthritis. Sci World J. 2012; http://dx.doi.org/10.1100/2012/841375

Santos T, Matos MG, Simões C, Camacho I, Tomé G, Moreno MC. Estilos Parentais E Desenvolvimento Positivo Em Crianças e Adolescentes Com Doença Crónica [Parenting styles and positive development in children and adolescents with chronic condition]. Revista de Psicologia da Criança e do Adolescente/J Child Adolesc Psych. 2013a;4(2):185-204. http://revistas.lis. ulusiada.pt/index.php/rpca/article/view/429/409

Santos T, Matos MG, Simões MC, Fonseca H, Machado MC. Individual factors related to chronic condition in Portuguese adolescents: Highlights from the HBSC/WHO Study. Health Spec Issue Chron Dis Res. 2013b;5(11B):25-34. http://dx.doi.org/10.4236/health.2013.511A2005

Santos T, Ferreira M, Simões MC, Matos MG, Machado MC. Chronic condition and risk behaviours in Portuguese adolescents. Glob J Health Sci. 2014;6(2):227-36. http://dx.doi.org/10.5539/gihs.v6n2p227.

Santos T, Matos MG, Simões C, Machado MC. Psychological well-being and chronic condition in Portuguese adolescents. Int J Adolesc Youth. 2015; http://dx.doi.org/10.1080/02673843.2015.1007880

Simões C, Matos MG, Tomé G, Ferreira M, Chaínho H. School satisfaction and academic achievement: the effect of school and internal assets as moderators of this relation in adolescents with special needs. Procedia Soc Behav Sci. 2010:9:1177-81. http://dx.doi.org/10.1016/.sbspro.2010.12.303.

Taylor RM, Gibson F, Franck LS. A concept analysis of health-related quality of life in young people with chronic illness. J Clin Nurs. 2008;17(14):1823-33. http://dx.doi.org/10.1111/j.1365-2702.2008.02379.x

Tomé G, Matos MG, Camacho I, Celeste C, Diniz JA. Portuguese adolescents: the importance of parents and peer groups in positive health. Span J Psychol. 2012:15(3):1315-24. http://dx.doi.org/10.5209/rev_SJOP.2012.v15.n3.39417.

Verhoof E, Maurice-Stam H, Heymans H, Grootenhuis M. Growing into disability benefits? Psychosocial course of life of young adults with a chronic somatic disease or disability. Acta Paediatrica. 2012;101:19-26. http://dx.doi.org/10. 1111/j.1651-2227.2011.02418.x

\section{Submit your manuscript to a SpringerOpen ${ }^{\circ}$ journal and benefit from:}

- Convenient online submission

- Rigorous peer review

- Immediate publication on acceptance

Open access: articles freely available online

- High visibility within the field

- Retaining the copyright to your article

Submit your next manuscript at $>$ springeropen.com 